\title{
Employment Intensity of Economic Growth: Evidence from Nepal
}

\author{
Madhav Prasad Dahal, PhD \\ Professor of Economics \\ Correspondence: madhavdahal3@gmail.com \\ Hemant Rai \\ Lecturer of Economics \\ Patan Multiple Campus, Tribhuvan University
}

\begin{abstract}
Economic growth and employment are taken as the top twin objectives of macroeconomic policy agenda in both developed and developing countries. Economic growth brings changes in employment growth. In general, during time of the growth of gross domestic product (GDP) increasing employment opportunities are created while unemployment will be rising during economic deceleration. This paper examines employment intensity of growth in (i) the economy of Nepal in totality, (ii) three broad economic sectors, and (iii) different sub-sectors of the economy over the period 1998-2018. Empirical result indicates labor-intensive growth in Nepal over the review period. There is no indication of jobless growth.
\end{abstract}

Keywords: Employment intensity, economic growth, labour productivity, sectoral output

JEL Codes: E24, J23

\section{BACKGROUND}

Economic growth and employment are taken as the twin objectives of macroeconomic policy agenda in both developed and developing countries. Economic growth brings changes in employment growth. In general, during time of the growth of gross domestic product (GDP) increasing employment opportunities are created but unemployment will be rising during the time of fall in economic growth (Boltho \& Glyn, 1995). Increase in employment due to economic growth brings new areas and better opportunities of earning income. Similarly, several sectors activated in the course of economic growth ultimately help reduce poverty (Islam, 2004).

Economic growth and employment are intrinsically linked. Economic growth creates new jobs but its intensity is different in different countries and different time (Kapsos, 2005; Döpke, 2001). During economic growth labour market responds differently. Hence the study of employment intensity of growth is important. 
The aim of the present study is to provide an empirical investigation on the ability of Nepal's economy to generate jobs. Employment elasticities vary considerably across production sectors. This paper addresses this issue. It examines the association between employment intensity and gross value added (GVA) of Nepalese economy, GVA of three broad economic sectors: primary(agriculture), secondary (industry) and tertiary(service), and extending it to different sub-sectors of the economy following International Standard Industrial Classification (ISIC) and Nepal Standard Industrial Classification (NSIC).

The employment intensity of overall and sectoral economic growth is an issue that merits in-depth study and analysis by reason of its direct impact on economic policies in Nepal. Economists and policy makers use a set of indicators to measure the ability of the national economy in general or of some of its sectors in particular, to create sufficient jobs to absorb new candidates to the labour market. These indicators include employment elasticity with respect to output, unemployment rates, rates of participation in economic activity, and ratios of employed persons to the population. This paper has chosen the employment elasticity with respect to growth in overall and sectoral gross value-added as an indicator to search employment intensity of growth.

Sectoral composition of the economy is considered as yet another important factor. Structural change in favour of fast-growing and job-intensive sectors may lead to an improvement in the employment intensity of growth (Mourre,2006). Therefore, the consideration of sectoral employment intensity of growth in the context of Nepal, a developing country, is time relevant from policy perspective. The issue of employment intensity of overall and sectoral economic growth seems an under-researched area in the context of Nepal as there have been very few studies to address this issue. The present study is an attempt to add an empirical evidence in the existing stock of knowledge with a fresh estimate of the issue.

Organizationally, this paper comprises of five sections. Following the introduction, section 2 provides an overview of previous empirical evidence on the association between employment elasticity and economic growth. Section 3 describes basic concepts, analytical framework and data used in the study. Section 4 presents the empirical results. And finally, section 5 offers concluding remarks.

\section{REVIEW OF PREVIOUS EMPIRICAL WORKS}

Because increase in employment opportunities and increase in economic growth is a key macroeconomic goal of every nation, many scholars have carried a number of country-specific and some cross-country empirical studies to investigate the employment intensity of economic growth. The review is not exhaustive; it makes cursory survey of previous studies undertaken after 1995 that have explored the issue of job creation in an attempt of achieving economic growth. 
Choosing 16 OECD (Organisation for Economic Co-operation and Development) countries, Boltho and Glyn (1995) examined the concept of employment intensity of growth exploiting data of the period 1960-1963. This study provided the evidence that geometric method produced no robust results but econometric estimates confirmed a positive long-run relationship between economic growth and employment over the whole sample period of the study. Estimates over sub-periods provided evidence of a stable link between employment and growth where out-employment intensity ranged between 0.5 and 0.6 .

In order to know the extent of employment intensity of growth in the G-7 economies, Padalino and Vivarelli (1997) investigated the issue taking data of the period 19601994.They argue that the long-run link between employment and growth is different from the short-run relationship. The result indicated that North America was more job intensive in the long term than Europe despite that they exhibited a similar job creation ability in short term. They explain this finding by the structural difference between the selected regions.

Using different pooling panel methods, Islam and Nazara (2000) estimated the average long-term intensity in Indonesia over the period of 1977-1996. They documented employment intensity between 0.49 and 0.66 . But all their econometric estimates suggested an unstable short-run linkage between growth and employment over the sub-periods.

Seyfried (2005) examined the ability of United States' economy to generate employment and economic growth concentrating in ten largest states of America. The estimates showed that employment intensity of growth over the period 1990-2003 varied from 0.31 to 0.61 across sates and it was around 0.47 for the overall sample. The author observed that employment responded immediately to economic growth and this effect continued for several quarters.

Using pooled regression with country dummy, Kapsos (2005) estimated employment intensity of growth over the period 1991-2003. The estimates showed that employment elasticities in the sampled countries over the covered-period varied globally between 0.3 and 0.38 , and which were explained mainly by the size of countries' service sector. This finding linked the ability of national job creations to the sectoral composition of economic growth. The study of Mourre (2006) that used a dynamic simulation approach explains that partly the aggregate employment growth observed between 1997 and 2001 in the euro area was by the growth of job shares in services sector. 
A Turkey-specific study on employment intensity of growth in manufacturing industry was performed by Aydiner-Avşar and Onaran (2010) using firm-level micro-data of the period 1973-2001.The study uncovered economic-sectors requiring low skilledlabour were more job-intensive than high - and medium-skill workers. Authors analyze that the specialization in low-skilled sectors reduce the long-term ability of Turkey's economy to generate employment opportunities since it's facing an increased competitive pressure from countries characterised with a plenty of lower-skilled and lower-wage labour. They pointed out the need of an industrial policy oriented-towards higher-skill and high-value-added activities.

Using data of the period 1991 to 2009 from 167 countries, Crivelli, Furceri and ToujasBernaté (2012) estimated the long-run employment intensity of growth applying timeseries and panel data regression. These two methods of estimate provided slightly differing employment elasticities for the sampled countries. Results showed that long term employment intensities varied considerably across regions in which the highest estimates were found for South Asia (0.99) followed by North America (0.81) and Western Europe (0.64).Other regions showed lower long-term employment intensities of growth for example Eastern Europe (0.23), Middle East and North Africa (MENA) region (0.1), and it was negative for sub-Saharan African countries (-0.02). As regard to the employment intensities at sectoral level, this study produced the evidence that agriculture, industry and services sectors contributed significantly in employment generation and were more labor-intensive in advanced economies.

With the objective of examining the long-term ability of Tunisian economic sectors to generate employment opportunities, Sassi and Goaied (2016) conducted an empirical study using a panel data of 15 Tunisian sectors over the period 1983-2010. They estimated the long-run output-employment elasticities by Mean Group Model. Their result revealed that the mining sector couldn't play a key role in reducing long-term unemployment given its incapacity to absorb labour. The long-run jobless growth of Hotels, Bars and Restaurants sector suggested that investment strategy in this sector reached its limits. The study prescribed that economic policy should target the most labour intensive sectors, services and exporting, and future policy priorities for the tourism sector should be Para-tourist attractions.

Adegboye, Egharevba and Edafe (2019) examined the impact of economic regulation on the employment elasticity of output growth for a group of 37 sub-Saharan Africa (SSA) countries for the period 1991-2014 using the Feasible Generalized Least Squares (FGLS) technique. Employment elasticities were estimated for the three sub-sample periods of 1991-1999, 2000-2009 and 2010-2014.Employment elasticities were higher during the period when growth rate was highest (2010-2014). Elasticity of total employment 
was low during the 1991-1999 period. Authors argue that market-based conditions may not be enough to generate employment-growth in a dual-sector economy. As an alternative, the level of regulation based on institutional capacity of government also provides strong background for improving the relationships. Empirical analysis in the study shows that there is a strong distinction between active regulation and institutional quality in terms of their effects on employment elasticities.

Mkhize (2019) investigated how sectoral employment intensity of output growth in the eight non-agricultural sectors of the South African economy evolved in the period from first quarter of 2000 to the fourth quarter of 2012, with a view to identifying crucial growth sectors that are employment-intensive. Empirical findings of the study suggested that total non-agricultural employment and GDP did not move together in the long-run, implying that jobless growth occurred in South Africa during the period under review. The author claims that this result supported the view that South Africa became less labor-intensive and more capital-intensive. However, results of sectoral composition supported a long-run association between employment and output growth in the finance and business services, manufacturing, transport and utilities sectors. The paper concludes by pointing out the need for increasing investment in the tertiary sector (the service sector) to foster new employment opportunities that could assist in improving overall employment intensity in South Africa.

To the best of authors knowledge, there are very scant empirical studies investigating the employment intensity of growth in the context of Nepal. In a study Kapsos (2005) estimated the employment intensity of growth for Nepal for the three periods of 19911995, 1995-1999 and 1999-2003. The estimates were limited to the three broad economic sectors: primary, secondary and tertiary, and covered time span is relatively short. With the objective of estimating the effect of economic liberalization implemented in Nepal since the mid-1980s, Shrestha (2017) examined the changes in structure, employment and productivity in the Nepalese economy for the period of 1991-2011.Based on the World Bank's sectoral growth decomposition method, empirical evidence shows that despite some structural changes through economic liberalization process Nepalese economy remained sluggish in employment generation and structural changes could not be growth enhancing. The study pointed out the need for policy devises from the government to generate employment in high productive sectors in order to increase both employment and productivity in the economy to raise per capital income. There has been structural shift in the Nepalese economy with the declining share of agriculture and manufacturing sectors dominated by the increased share of the service sector in the gross value added (GVA) of the economy more apparently after 2000 (Dahal, 2016). 
The association between growth and its employment and productivity intensity goes on changing over time; the trend and pattern observed over a certain period and in a country or region would not be applicable all the time and place. The present paper considers overall and sectoral employment intensity and labour productivity of growth in the context of Nepal taking relatively later period (1998-2018) data generated from Nepal Labour Force Survey Reports of 1998, 2008 and 2018.It brings result of fresher estimate of the issue.

\section{CONCEPTS AND ANALYTICAL FRAMEWORK}

Employment Intensity of Growth is commonly measured by taking the ratio of the percentage change in employment to percentage change in output. The resulting number indicates employment creation capacity of the economy or a sector of the economy. Simply, the arithmetic measure of employment intensity of growth is expressed as:

$\varepsilon=\frac{\% \Delta E}{\% \Delta Y}$

Where, $\varepsilon$ (Grrek letter epsilon) is a symbol indicating employment intensity of growth; $\% \Delta \mathrm{E}$ is percentage change in labour employment, and $\% \Delta \mathrm{Y}$ is percentage change in output growth.

Though the arithmetic method of measuring employment intensity of growth is simple, it is not robust and it may be biased in inter-country comparison (Islam, 2004; Islam \& Nazara, 2000). Therefore, many scholars working in this area use the following form of regression equation to measure the employment intensity of growth:

$\ln E_{t}=\alpha+\beta \ln Y_{t}+u_{t} \ldots \ldots(2)$

Where, $\mathrm{E}=$ =Employment, $\mathrm{Y}=$ Output, $\alpha=$ Intercept term; $\beta=$ Employment intensity $/$ elasticity coefficient, $\mathrm{u}=$ Error term, and $\mathrm{t}$ is an index of time.

The estimated numerical value of $\beta$ in equation (2) gives the measure of employment intensity of growth. The value of the elasticity obtained from the estimate of $\beta$ measures the response of employment to economic growth. Islam (2004), however, reminds that economic growth is affected by both increase in employment and rise in productivity and hence cautions is required to interpret the relationship between elasticity of employment, growth in employment and productivity. Kapsos (2005) suggests a 'fundamental identity' between employment intensity of growth and labour productivity elasticity of growth as depicted in equation (3): 
$\mathrm{Y}=\mathrm{E} \times \mathrm{P}$

Where $\mathrm{Y}\left(\mathrm{P}=\frac{\mathrm{Y}}{\mathrm{E}}\right)$ is output, $\mathrm{E}$ is employment and $\mathrm{P}$ is productivity of labour (output per worker) .

Then taking log on both sides of equation (3) gives,

In $\mathrm{Y}=\operatorname{In} \mathrm{E}+\operatorname{In} \mathrm{P}$

Differentiating both sides of Equation (4) with time variable t:

$\frac{d(\ln Y)}{d Y} \frac{d Y}{d t}=\frac{d(\ln E)}{d E} \frac{d E}{d t}+\frac{d(\ln P)}{d P} \frac{d P}{d t}$

Taking discrete time rather than continued version, equation (5) can be written as

$$
\Delta \mathrm{Y} / \mathrm{Y}=\Delta \mathrm{E} / \mathrm{E}+\Delta \mathrm{P} / \mathrm{P}
$$

Dividing both sides of equation (6) by $\Delta \mathrm{Y} / \mathrm{Y}$ results

$$
1=\frac{\Delta \mathrm{E} / \mathrm{E}}{\Delta \mathrm{Y} / \mathrm{Y}}+\frac{\Delta \mathrm{P} / \mathrm{P}}{\Delta \mathrm{Y} / \mathrm{Y}}
$$

As $\frac{\Delta E / E}{\Delta Y / Y}$ is employment intensity of growth, $\varepsilon$, equation (7) gives:

$$
\varepsilon=1-\frac{\Delta P / P}{\Delta Y / Y}
$$

Where, $\frac{\Delta P / P}{\Delta Y / Y}$ is the productivity intensity of growth.

Equation (8) expresses how employment intensity of growth and intensity of labourproductivity of growth are interconnected. It shows that the elasticity of employment with respect to gross domestic product $(\mathrm{GDP}=\mathrm{Y})$ is equal to 1 minus the elasticity of labour productivity. Looking into changes in output together with employment elasticity gives a picture as to whether growth in a country is occurring together with gains in employment and labour productivity, or whether it is balanced between the two.

Using equation (8) we can interpret different scenarios of economic growth and association between employment elasticity and changes in employment and labour productivity. A summary of this relationship is given in Table 1. 
Table 1: Employment Elasticity and Changes in Employment and Labour Productivity

\begin{tabular}{|l|l|l|}
\hline \multirow{2}{*}{$\begin{array}{c}\text { Employment } \\
\text { Elasticity Values }\end{array}$} & \multicolumn{2}{|c|}{ GDP Growth } \\
\cline { 2 - 3 } & Positive GDP growth & Negative GDP growth \\
\hline $\boldsymbol{\varepsilon}<\mathbf{0}$ & Negative (-) employment growth. & Positive (+) employment growth. \\
& Positive (+) productivity growth. & Negative (-) productivity growth. \\
\hline $\boldsymbol{\varepsilon}>1$ & Positive (+) employment growth. & Negative (-) employment growth. \\
& Positive (+) productivity growth. & Negative (-) productivity growth. \\
\hline & Positive (+) employment growth. & Negative (-) employment growth. \\
& Negative (-) productivity growth. & Positive (+) productivity growth. \\
\hline
\end{tabular}

Source: Kapsos (2005).

Positive employment elasticity coefficient close to unity suggests that economic growth leads to an increase in employment, and rate of employment elasticity close to zero indicates a low association between economic growth and employment. Thus, in this case the phenomenon of jobless economic growth occurs.

\section{DATA}

The data on gross value added (GVA) of the entire economy and its different sectors is taken from National Account data published by the Central Bureau of Statistics (CBS), Government of Nepal. As the time series data of employment of labour force in Nepal are not available, the data on employment were generated through interpolation by using employment figures of Nepal Labour Force Survey Reports (NLFSRs) 1998/99, 2008 and 2017/18 of Central Bureau of Statistics (CBS). The simple reason for choosing the sample period of 1998-2018 is that the first Labour Force Survey (LFS) in Nepal was completed in 1998/99 and the latest one was accomplished in 2017/18 and these surveys provided more reliable data on employment in Nepal.

Friedman (1962) enunciated on the use of interpolation with the assertion that: "Most economic time series are highly manufactured products, constructed out of many bits and pieces that must be shaped and rearranged to yield the final series. One of the commonest operations performed in this process is the interpolation...". With decennial census or labour force survey as of Nepal the data of two censuses bound the estimate date and contain information that implicitly and explicitly bound the estimate itself, an interpolation method is more likely to produce more accurate estimates than an extrapolative method, and is of higher utility (Swanson \& Tayman, 2012). As such it is reasonable to follow the interpolation method in generating the time series on labour-force from the available data points. To the extent that there is no 
all-agreed method of interpolating population in between two censuses, in this study we use the following exponential growth curve fitting mathematical formula to get the population for the inter-survey years:

$\mathrm{P}_{\mathrm{t}}=\mathrm{P}_{0} \mathrm{e}^{\mathrm{rt}}$

where $\mathrm{P}_{\mathrm{t}}$ is the population of a particular year $\mathrm{t}, \mathrm{P}_{0}$ is the initial population (i.e., the population of the base census year), $\mathbf{e}$ is the base of the system of natural logarithm (ln) equal to 2.71828 (the base of natural logarithm allows for calculation of a constant rate of change where the absolute amount of change varies over time), $r$ is the average annual rate of population growth, and $t$ is the index of time.

\section{RESULTS AND DISCUSSION}

Following previous literature, equation (2) is estimated by using the ordinary least squares (OLS) method. In the OLS estimates the first order autocorrelation, AR (1), among the residuals is corrected for all equations as the Durbin-Watson statistic was low without AR (1). The estimate is made for the aggregate economy as well as for three broad economic sectors and majority of different sub-sectors of the economy. Employment elasticity coefficients obtained from the estimate of the regression equation using time series data of the period 1998-2018 is given in Table 2 in which labour-productivity intensity of growth in the last column is arrived at as a residual using equation (8).

\begin{tabular}{|l|l|l|l|l|l|l|}
\hline \multicolumn{7}{|c|}{ Table 2: Employment Intensity of Growth, Nepal,1998-2018 } \\
\hline S.N. & $\begin{array}{l}\text { Sectors and Gross } \\
\text { Value Added } \\
(\text { GVA })\end{array}$ & $\begin{array}{l}\text { Employment } \\
\text { Intesity of } \\
\text { Growth } \\
(\varepsilon=\Delta \mathrm{E} / \Delta \mathrm{Y})\end{array}$ & $\begin{array}{l}\text { Std. } \\
\text { Error }\end{array}$ & t-Statistic & Prob. & $\begin{array}{l}\text { Productivity } \\
\text { Intesity of } \\
\text { Growth } \\
(\Delta \mathrm{P} / \Delta \mathrm{Y}=1-\varepsilon)\end{array}$ \\
\hline 1 & $\begin{array}{l}\text { GVA of the } \\
\text { Economy }\end{array}$ & 0.649 & 0.019 & 34.155 & 0.000 & 0.351 \\
\hline 2 & Agriculture & 0.517 & 0.092 & 5.643 & 0.000 & 0.483 \\
\hline 3 & Non-Agriculture & 0.684 & 0.164 & 4.169 & 0.001 & 0.316 \\
\hline 4 & Industry & 0.763 & 0.333 & 2.291 & 0.035 & 0.237 \\
\hline 5 & Service Sector & 0.440 & 0.140 & 3.150 & 0.006 & 0.560 \\
\hline 6 & $\begin{array}{l}\text { Mining and } \\
\text { Quarrying Sector }\end{array}$ & 1.398 & 0.498 & 2.805 & 0.012 & -0.398 \\
\hline 7 & $\begin{array}{l}\text { Manufacturing } \\
\text { Sector }\end{array}$ & 0.579 & 0.244 & 2.373 & 0.029 & 0.421 \\
\hline
\end{tabular}

(Table continued) 


\begin{tabular}{|l|l|l|l|l|l|l|}
\hline \multicolumn{7}{|c|}{ (Table 2 continued) } \\
\hline 8 & $\begin{array}{l}\text { Electricity, } \\
\text { Gas and Water } \\
\text { Supply }\end{array}$ & 0.618 & 0.419 & 1.477 & $0.158^{*}$ & 0.382 \\
\hline 9 & Construction & 0.156 & 1.497 & 0.104 & $0.919^{*}$ & 0.844 \\
\hline 10 & Trade and Hotel & 0.181 & 0.074 & 2.434 & 0.026 & 0.819 \\
\hline 11 & $\begin{array}{l}\text { Transport and } \\
\text { Communication }\end{array}$ & 1.123 & 0.061 & 18.551 & 0.000 & -0.123 \\
\hline 12 & $\begin{array}{l}\text { Finance, } \\
\text { Insurance and } \\
\text { Real Estate }\end{array}$ & 0.803 & 0.215 & 3.732 & 0.002 & 0.197 \\
\hline 13 & $\begin{array}{l}\text { Community, } \\
\text { Social and } \\
\text { Personal Service }\end{array}$ & 0.429 & 0.294 & 1.459 & $0.163^{*}$ & 0.571 \\
\hline
\end{tabular}

*regression coefficient insignificant at conventional level of significance. Source: Authors computation

Facts and figures of Table 2 indicate that Nepal experienced employment enhancing growth over the period 1998-2018 with different employment intensity of growth in different economic sectors of the economy. In terms of the overall gross value added (GVA) of the economy, the coefficient of employment intensity of growth is 0.649 which would mean that all else being equal 1 percentage point growth in the GVA in the economy was associated with 0.65 percentage point growth in employment. The positive coefficient is statistically significant at higher level of precision. In Kapsos's (2005) study of employment intensity of growth for a group of countries it was found that the employment elasticity of growth for Nepal for the three periods 1991-1995, 1995-1999 and 1999-2003 were 0.35, 0.46 and 0.64 respectively. Khan (2001) argues that until developing countries be able to promote themselves in upper-middle-income group, they should aim at achieving an employment elasticity of 0.7 on the average. He further adds that there is obviously a conflict between a high output elasticity of employment and a rapid growth in labour productivity. A healthy balance between the two depends on the specific situations of a country. As a general rule, a country with a high incidence of poverty and a relatively large quantity of labour resources, will help its poor more by focusing on a higher elasticity of employment than on a higher growth in labour productivity.

As seen in Table 2 employment intensity of growth in the Mining and Quarrying and in the Transport and Communication sectors appears in excess of one. The estimated elasticity coefficient would mean that one percentage point increase in the gross value added of the Mining and Quarrying Sector generated 1.39 percentage point growth in employment. Similarly, near about 1.12 percentage point job creation was associated 
with one percentage point growth in the gross value added of the Transport and Communication sector. But then again in these two economic sectors elasticity of labour productivity is negative.

Adhering to Khan (2001) when employment elasticity is greater than one it indicates a lower productivity of employment at the margin than on the average. He suggests that normally a country should avoid this outcome. However, this does not mean that an elasticity greater than one is necessarily a bad thing. A country, initially characterised by an undesirably highly capital-intensive technology with restricted employment, may benefit from a very different composition of incremental output representing a higher rate of growth in employment than in output, signifying a lower, and socially more desirable, capital-intensity at the margin. But one needs to be convinced that the higher-than-unit elasticity of employment is consistent with efficient labour use.

The estimated employment elasticity of growth for the three economic sectors (i) Electricity, Gas and Water Supply, (ii) Construction, and (iii) Community, Social and Personal Services is not statistically significant at the conventional levels of significance (i.e., at the significance level of $0.01,0.05$ and 0.1 ). The insignificant coefficient would mean that job creation in these sectors of the economy of Nepal over period under review was not substantial. When compared to previous studies, the results obtained in this estimate are similar to the findings of Mkhize (2019) specifically carried in the context of South Africa.

In sum Table 2 reveals that there was positive employment and labour productivity intensity of growth in the Nepalese economy as a whole and in sectors like agriculture, non-agriculture, industry, service, manufacturing, electricity, gas and water, construction, trade and hotel, finance, insurance and real estate, and community, social and personal services. The general assertation is that if the employment elasticity lies between zero and one $(0 \leq \varepsilon \leq 1)$, an economy with positive GDP will experience positive employment and productivity growth. This is an exceptional situation for any economy with an increase in employment together with productivity gains. It is worthy to understand that both employment elasticity growth and productivity growth are required in any economy in order to reduce poverty. The reason for this is that while employment elasticity growth gives the quantitative aspect of employment growth, productivity growth is the qualitative feature of employment growth and hence one side should not be emphasized more than the other.

World Bank (2018) looking at employment figures in South Asia observed that several South Asian countries' employment rates were below those of other countries at a similar level of development. It remarks that Nepal remained an exception as its 
employment rate was higher than that of many other countries with similar GDP per capita. In Bangladesh, India, Sri Lanka, and Pakistan, employment rates were observed much below what is predicted given their income per capita.

\section{CONCLUSION}

This paper has empirically investigated the employment creation ability of Nepal's economy using data spreading over the period of 1998-2018.It has examined the association between employment intensity and gross value added (GVA) of the whole economy, three broad economic sectors: primary (agriculture), secondary (industry) and tertiary (service), and extended the investigation to many sub-sectors of the economy as specified in the framework of International Standard Industrial Classification (ISIC) and Nepal Standard Industrial Classification (NSIC).

The result supported the view that Nepal remained more labor-intensive and less capital-intensive over the review period of 1998-2018. With the exception of Mining and Quarrying and Transport and Communication sectors, the employment intensity of growth in Nepal over the sample period lies between zero and one $(0 \leq \varepsilon \leq 1)$ which implies that overall and sectoral gross value added (GVA) growth in Nepal led employment and productivity growth. This is an ideal situation for any economy with an increase in employment together with marginal productivity gains. This study does not find indication of jobless growth in Nepal over the period 1998-2018. An apparent caveat of this study is that it has not considered other determinants of employment over which future studies might delve.

There is a hard choice to the policy makers. An implication for the public policy makers is that it is not easy to reduce poverty without increasing labour productivity of growth. To bring more productivity growth the production sector of the economy should dynamically move from labour-intensive towards moderately capitalintensive production activities over which employment intensity of growth would be compromised. Increasing employment opportunity followed by increased productivity is a challenging goal demanding government's commitment, rigor in policy making, project selection and their implementation.

Acknowledgement: Authors would like to gratefully acknowledge the valuable comments and suggestions on the paper offered by Prof. Dr. Nav Raj Kanel. The usual disclaimer applies. 


\section{REFERENCES}

Adegboye, A., Egharevba, M.I., \& Edafe, J. (2019). Economic regulations and employment intensity of output growth in sub-Saharan Africa. In A. B. Elhiraika, G. Ibrahim \& W. Davis (Eds.), Governance for structural transformation in Africa (pp.101-144). Palgrave Macmillan.

Aydiner-Avşar, N., \& Onaran, Ö. (2010). The determinants of employment: A sectoral analysis for Turkey. The Developing Economies,48(2), 203-231.

Boltho, A., \& Glyn, A. (1995). Can macroeconomic policies raise employment? International labour Review, 134, 451-470.

Crivelli, E., Furceri, D., \& Toujas-Bernaté, J. (2012). Can policies affect employment intensity of growth? A cross-country analysis. IMF Working Paper WP/12/218. Accessed from https://www.imf.org/en/Publications/WP/Issues/2016/12/31/CanPolicies-Affect-Employment-Intensity-of-Growth-A-Cross-Country-Analysis-26230

Dahal, M.P. (2016). Stride of service sector in Nepal's trajectories of structural change. Economic Journal of Development Issues, $21 \mathcal{E} 22$ (1-2), 69-98. DOI: https://doi. org/10.3126/ejdi.v21i1-2.19024

Döpke, J. (2001). The employment intensity of growth in Europe. Kiel Working paper No.1021. Retrieved from https://www.ifw-kiel.de/fileadmin/Dateiverwaltung/IfWPublications/system/the-employment-intensity-of-growth-in-europe/kap1021.pdf

Friedman, M. (1962). The interpolation of time series by related series. The Journal of American Statistical Association, 57, 729-757.

Government of Nepal, Ministry of Finance. (2018). Economic survey 2017/18. Kathmandu: Author.

Government of Nepal, Central Bureau of Statistics. (2018). Labour force survey 2017/18. Thathali, Kathmandu: Author

Islam, R. (2004). The nexus of economic growth, employment and poverty reduction: An empirical analysis. Geneva: Recovery and Reconstruction Department, International Labour Office.

Islam, I., \& Nazara, S. (2000). Estimating employment elasticity for the Indonesian economy. ILO Technical Note, Jakarta.

Khan, A. (2001). Employment policies for poverty reduction. Geneva: Recovery and Reconstruction Department, International Labour Office

Kapsos, S. (2005). The employment intensity of growth: Trends and macroeconomic determinants (International Labour Office, Employment Strategy Papers No 12). Geneva: Employment Trends Unit, International Labour Office. 
Mkhize, N.I. (2019). The sectoral employment intensity of growth in South Africa. Southern African Business Review,23, 24 pages. Retrieved from: https://doi. org/10.25159/1998-8125/4343

Mourre, G. (2006). Did the pattern of aggregate employment growth change in the euro area in the late 1990s? Applied Economics, 38 (15), 1783-1807. doi: $10.1080 / 00036840500427072$

Padalino, S., \& Vivarelli, M. (1997). The employment intensity of economic growth in the G-7 countries, International Labour Review, 136 (2),191-213.

Sassi, S., \& Goaied, M. (2016). Long-term employment intensity of sectoral output growth: Evidence from Tunisia. International Labour Review,155(2),253-263. https://doi.org/10.1111/j.1564-913X.2015.00034.x

Seyfried, W. (2005). Examining the relationship between employment and economic growth in the ten largest states. Southern Economic Review,32 (1),13-24.

Shrestha, P.K. (2017). Economic liberalization in Nepal: Evaluating the changes in economic structure, employment and productivity. Journal of Development Innovations,1(1),60-83. www. karmaquest.org/journal

Swanson, D.A., \& Tayman, J. (2012). Subnational population estimates. New York: Springer.

World Bank. (2018). South Asia economic focus: Jobless growth? Accessed from https://doi. org/10.1596/978-1-4648-1284-2 